[Chem. Pharm. Bull.

35(10)4324-4327(1987)

\title{
Inhibition of Adenosine Triphosphatase Activity in Brain Microtubule Proteins by S100 Protein
}

\author{
Toshihiro FujiI, ${ }^{* a}$ Haruo AsaI, ${ }^{a}$ YUKIHIRo MiYasaka, ${ }^{a}$ \\ TATSUO SUZUKI, ${ }^{b}$ and YOSHIYUKI KONDO ${ }^{a}$ \\ Faculty of Textile Science and Technology, Shinshu University, ${ }^{a}$ 3-15-1, Tokida, \\ Ueda, Nagano 386, Japan and Department of Biochemistry, Nagoya City \\ University, Medical School, ${ }^{b}$ Nagoya 467, Japan
}

(Received April 1, 1987)

\begin{abstract}
S100 protein exhibited an inhibitory effect on the adenosine triphosphatase activity of brain microtubule proteins in a concentration-dependent manner. In the presence of $\mathrm{Ca}^{2+}$, maximal inhibition was about $90 \%$ (only about $10 \%$ of the original activity remained), while the maximum inhibition in the presence of $\mathrm{Mg}^{2+}$ was about $30 \% . \mathrm{Zn}^{2+}$, which can bind both microtubule proteins and S100 protein, had little effect on the inhibitory action of S100 protein in the presence or absence of $\mathrm{Ca}^{2+}$. The inhibition by $\mathrm{S} 100$ protein was reduced by chlorpromazine.
\end{abstract}

Keywords_—S100 protein; microtubule protein; ATPase; chlorpromazine; zinc; calcium

Microtubules have architectural and contractile roles in nearly all eucaryotic cells; for example, they are involved in axonal transport, chromosomal movement and hormonal secretion. ${ }^{1)}$ The motive force of cell motility depends on the hydrolysis of adenosine $5^{\prime}$ triphosphate (ATP). It has been reported that an ATPase activity is present in brain microtubule proteins. ${ }^{2-4)}$ The activity is insensitive to several inhibitors of membrane ATPase and remains bound to the microtubule proteins through successive cycles of polymerization and depolymerization. ${ }^{3,4)}$ These results suggest that ATPase in microtubule proteins is associated with the motility of cytoplasm.

S100 protein has been shown to regulate microtubule assembly and disassembly ${ }^{5-7}$ and the phosphorylation of several proteins. ${ }^{8,9)}$ These regulations are $\mathrm{Ca}^{2+}$ dependent. $\mathrm{S} 100$ protein also binds to $\mathrm{Zn}^{2+}$ with high affinity and induces the inhibition of microtubule assembly. ${ }^{6,10-12)}$ However, the functions of $\mathrm{S} 100$ protein have not been established in detail.

We report here that $\mathrm{S} 100$ protein inhibits $\mathrm{Ca}^{2+}$-ATPase activity in porcine brain microtubule proteins, and the inhibition by $\mathrm{S} 100$ protein is reduced by chlorpromazine.

\section{Materials and Methods}

Materials — Diethylaminoethyl(DEAE)-Sephadex A-50, and Sephadex G-75 were purchased from Pharmacia, 2-( $N$-morpholino)ethanesulfonic acid (MES) from Boehringer, Chlorpromazine from Sigma and $\left[\gamma^{32} \mathrm{P}\right] \mathrm{ATP}$ from ICN Radiochemicals. Other chemicals used were of the highest quality commercially available.

Preparation of Proteins $-\mathrm{S} 100$ protein and calmodulin were purified from porcine brain by ammonium sulfate fractionation followed by column chromatography on DEAE-Sephadex A-50 and Sephadex G-75. ${ }^{11,13)}$ Microtubule proteins were prepared from porcine brain by three cycles of temperature-dependent assembly and disassembly as described previously. ${ }^{14)}$

Assay for ATPase -ATPase activity was assayed by measuring the amount of inorganic phosphate released. In the standard assay of ATPase activity, the reaction mixture contained $60 \mathrm{~mm}$ MES-KOH (pH 6.5), $2 \mathrm{~mm} 2$ mercaptoethanol, $12.5 \%(\mathrm{v} / \mathrm{v})$ glycerol, $0.5 \mathrm{~mm}\left[\gamma-{ }^{32} \mathrm{P}\right] \mathrm{ATP}(4-6 \mu \mathrm{Ci} / \mu \mathrm{mol})$ and $20 \mu \mathrm{g}$ of microtubule proteins in a final volume of $50 \mu \mathrm{l}$. Reactions were initiated by the addition of substrate and stopped by the addition of $20 \mathrm{~mm}$ silicotungstic acid in $0.02 \mathrm{~N} \mathrm{H}_{2} \mathrm{SO}_{4}$ after incubation for $30 \mathrm{~min}$ at $37^{\circ} \mathrm{C}$. The liberation of inorganic phosphate was 
determined with a liquid scintillation spectrometer (Aloka, LSC-651). ${ }^{15)}$

Protein Concentration_-Protein was determined by the method of Lowry et al. ${ }^{16)}$ with bovine serum albumin as a standard.

\section{Results}

The effect of S100 protein on the ATPase activity of porcine brain microtubule proteins in the presence of $5 \mathrm{mM} \mathrm{Ca}^{2+}$ or $2 \mathrm{mM} \mathrm{Mg}^{2+}$ is shown in Fig. $1 . \mathrm{Ca}^{2+}$-ATPase activity was remarkably decreased with increasing concentration of S100 protein. The activity was only about $10 \%$ of the original level at over $0.8 \mathrm{mg} / \mathrm{ml} \mathrm{S100}$ protein. On the other hand, in the presence of $\mathrm{Mg}^{2+}$ the ATPase activity was decreased to a lesser extent by adding $\mathrm{S} 100$ protein. The concentrations of $S 100$ protein required for half-maximal inhibition were $0.31 \mathrm{mg} / \mathrm{ml}$ in the presence of $\mathrm{Ca}^{2+}$ and $0.41 \mathrm{mg} / \mathrm{ml}$ in the presence of $\mathrm{Mg}^{2+}$.

Calmodulin is a $\mathrm{Ca}^{2+}$-binding protein which is evolutionarily related to $\mathrm{S} 100$ protein and is present in large amounts in the brain. ${ }^{16)}$ When porcine brain calmodulin $(0-0.7 \mathrm{mg} / \mathrm{ml})$ was added to the reaction mixture instead of S100 protein, calmodulin had no effect on the $\mathrm{Ca}^{2+}$-ATPase activity of microtubule proteins (data not shown).

Figure 2 illustrates the dependence of the ATPase activity of microtubule proteins on $\mathrm{Ca}^{2+}$ concentration. ATPase activity without S100 protein was slightly stimulated by the addition of $\mathrm{Ca}^{2+}$. When $\mathrm{S} 100$ protein $(0.45 \mathrm{mg} / \mathrm{ml})$ was present, the ATPase activity decreased with increasing $\mathrm{Ca}^{2+}$ concentration, showing a plateau level at over $2 \mathrm{mM} \mathrm{Ca}{ }^{2+}$. These results suggest that high concentrations of $\mathrm{Ca}^{2+}$ are required for effective ATPase inhibition by S100 protein.

$\mathrm{Zn}^{2+}$ has been shown to bind both $\mathrm{S} 100$ protein and microtubule proteins. ${ }^{10-12,17)} \mathrm{We}$ therefore examined the effect of $\mathrm{Zn}^{2+}$ on the ATPase activity (Table I). In the absence of $\mathrm{Ca}^{2+}$ and $\mathrm{S} 100$ protein, the ATPase activity was found to be inhibited slightly by adding $\mathrm{Zn}^{2+}$ (S100 protein also did not effectively inhibit the ATPase activity in the absence of $\mathrm{Ca}^{2+}$ ). In the presence of $5 \mathrm{mM} \mathrm{Ca}^{2+}$, addition of $\mathrm{Zn}^{2+}$ did inhibit the ATPase activity, but the extent of

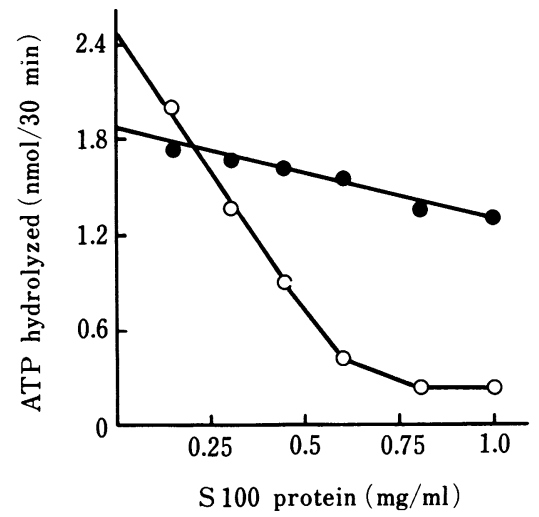

Fig. 1. Effect of S100 Protein on the ATPase Activity in Microtubule Proteins

ATPase activity was measured as described in Materials and Methods, in media containing $60 \mathrm{~mm}$ MES-KOH (pH 6.5), $2 \mathrm{~mm}$ 2-mercaptoethanol, $12.5 \%$ glycerol and $0.5 \mathrm{~mm}\left[\gamma_{-}{ }^{32} \mathrm{P}\right] \mathrm{ATP}$, made up to contain the indicated concentration of $\mathrm{S} 100$ protein. Results each represent the average of three individual experiments. The concentration of microtubule proteins was $0.4 \mathrm{mg} / \mathrm{ml}$. O, $5 \mathrm{~mm} \mathrm{CaCl}_{2} ; 0,2 \mathrm{~mm}$ $\mathrm{Mg}\left(\mathrm{CH}_{3} \mathrm{COO}\right)_{2}$.

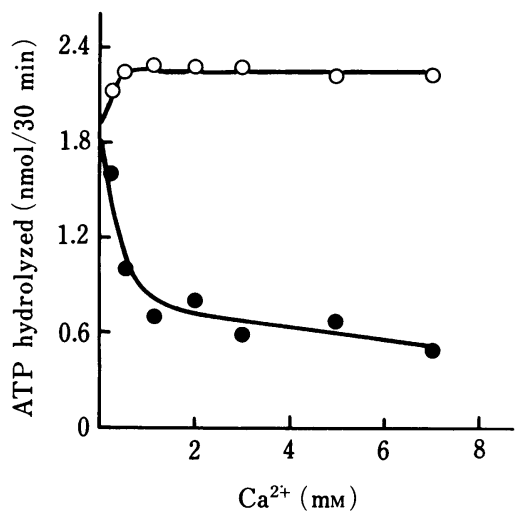

Fig. 2. Dependence on $\mathrm{Ca}^{2+}$ Concentration of ATPase Activity in the Presence or Absence of S100 Protein

Enzyme activity was measured under the standard conditions modified to the indicated concentrations of $\mathrm{Ca}^{2+}$. The concentrations of microtubule proteins and $\mathrm{S} 100$ protein were 0.4 and $0.45 \mathrm{mg} / \mathrm{ml}(21 \mu \mathrm{M})$, respectively. $\mathrm{O},(-) \mathrm{S} 100$ protein;,$(+) \mathrm{S} 100$ protein. 
TABLE I. Effect of $\mathrm{Zn}^{2+}$ on ATPase Activity in the Presence or Absence of S100 Protein

\begin{tabular}{clccc}
\hline \hline Conditions & $\begin{array}{c}\mathrm{Zn}^{2+} \\
(\mathrm{mM})\end{array}$ & $\begin{array}{c}(-) \mathrm{S} 100 \\
\mathrm{nmol} / 30 \mathrm{~min}\end{array}$ & $\begin{array}{c}(+) \mathrm{S} 100 \\
\text { Inhibition }^{a)} \\
(\%)\end{array}$ \\
\hline$(-) \mathrm{Ca}^{2+}$ & 0 & 1.74 & 1.24 & 29 \\
& 0.1 & 1.52 & 1.28 & 16 \\
& 0.2 & 1.48 & 1.26 & 15 \\
$(+) \mathrm{Ca}^{2+}$ & 0.4 & 1.38 & 1.30 & 6 \\
& 0 & 3.00 & 0.74 & 63 \\
& 0.1 & 1.50 & 0.56 & 74 \\
& 0.2 & 1.14 & 0.30 & 78 \\
\hline
\end{tabular}

Experimental conditions were the same as for Fig. 1 except that the concentration of $\mathrm{S} 100$ protein was $0.45 \mathrm{mg} / \mathrm{ml}$. a) "Inhibition" is the percent inhibition caused by $\mathrm{S} 100$ protein with respect to the ATPase activity under the same conditions except for the absence of S100 protein.

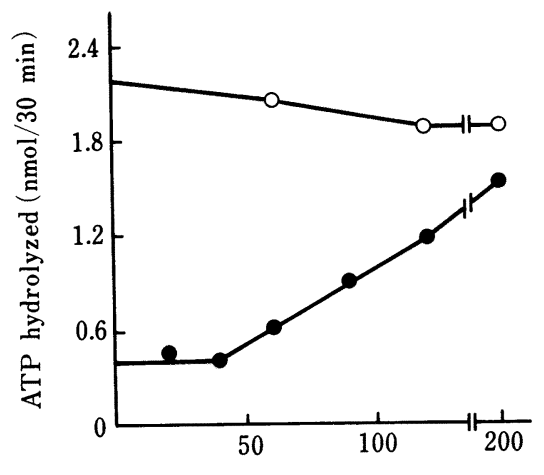

Chlorpromazine $\left(\mu_{\mathrm{M}}\right)$
Fig. 3. Effect of Chlorpromazine on $\mathrm{Ca}^{2+}$ ATPase Activity in the Presence or Absence of S100 Protein

Experimental conditions were the same as for Fig. 2 except that the concentration of $\mathrm{Ca}^{2+}$ was $5 \mathrm{~mm}$ and that of chlorpromazine was varied as indicated. $\bigcirc$, (-) S100 protein;,$(+) \mathrm{S} 100$ protein.

inhibition by $\mathrm{S} 100$ protein was high and almost constant, irrespective of $\mathrm{Zn}^{2+}$ concentration.

Chlorpromazine reduced the inhibitory effect of S100 protein in a dose-dependent manner under conditions where the ATPase activity was inhibited about $80 \%$ by $\mathrm{S} 100$ protein (Fig. 3). In the absence of S100 protein, the drug had little effect on the ATPase activity. The inhibition by $\mathrm{S} 100$ protein was markedly reduced by over $5 \mathrm{~mol}$ of chlorpromazine per mole of S100 protein. This value is about 5 times the molar ratio of chlorpromazine bound to S100 protein reported by Donato. ${ }^{18,19)}$

\section{Discussion}

The present study is the first to find that $\mathrm{S} 100$ protein inhibits the ATPase activity contained in brain microtubule proteins. The ATPase activity has been shown to be activated by non-physiologically high concentrations of $\mathrm{Ca}^{2+} .{ }^{15,20)}$ Potent inhibition by $\mathrm{S} 100$ protein was found at higher concentrations of $\mathrm{Ca}^{2+}$ (over $1 \mathrm{mM}$ ) (Fig. 2), while S100 protein had little effect on the activity at lower $\mathrm{Ca}^{2+}$ concentrations. The inhibition of microtubule assembly by S100 protein, on the other hand, was observed when the concentration of $\mathrm{Ca}^{2+}$ was $10^{-5}$ $10^{-4} \mathrm{M}^{5-7)}$ The binding affinity of $\mathrm{S} 100$ protein for $\mathrm{Ca}^{2+}$ has been calculated to be $0.1-$ $2 \times 10^{-4}$ M. $^{19)}$ Tubulin, a main component of microtubule proteins, also contains one highaffinity $\mathrm{Ca}^{2+}$ site $\left(3.3 \times 10^{-6} \mathrm{M}\right)$ and 16 low-affinity sites $\left(2.8 \times 10^{-4} \mathrm{M}\right){ }^{21)}$ Thus, the inhibitory effect of S100 protein may due to $\mathrm{Ca}^{2+}$ binding to tubulin as well as to S100 protein.

As shown previously, ${ }^{6,11,19)} \mathrm{S} 100$ protein in the presence of $\mathrm{Zn}^{2+}$ inhibits microtubule 
assembly. However, $\mathrm{Zn}^{2+}$ has no effect on the inhibition of microtubule ATPase activity by S100 protein (Table I). The molar ratio of S100 protein to tubulin required for half-maximal inhibition is about 5 , assuming that the content of tubulin in microtubule proteins is $75 \%$ (Fig. 1). On the other hand, we have reported that the molar ratio required to suppress the microtubule assembly is about 2 at $0.2 \mathrm{mM} \mathrm{Ca}^{2+} .^{7)}$ In addition, $\mathrm{Ca}^{2+}$ is one of the most potent inhibitors of microtubule assembly at high concentrations. ${ }^{22)}$ These results suggest that S100 protein has different effects on ATPase of microtubule proteins from those on the assembly.

It has been reported that chlorpromazine, an antipsychotic drug belonging to the phenothiazine group, binds to $\mathrm{S} 100$ protein. ${ }^{18,19,23)} \mathrm{S} 100$ protein can interact with phenothiazine-conjugated Sepharose 4B in a $\mathrm{Ca}^{2+}$-dependent fashion and the chlorpromazine binding results in a conformational change of $\mathrm{S} 100$ protein. Although the molar ratio of chlorpromazine bound to $\mathrm{S} 100$ protein has been reported to be about $1,{ }^{18,19,23)}$ low concentrations of chlorpromazine showed little effect on ATPase activity in the absence or presence of S100 protein under the conditions employed in the present study (Fig. 3). High concentrations of chlorpromazine were required to reverse the S100 protein-dependent inhibition of ATPase activity, indicating that low-affinity binding sites for chlorpromazine may be present on $\mathrm{S} 100$ protein.

Like S100 protein, calmodulin has been demonstrated to modulate the assembly of microtubule proteins in a $\mathrm{Ca}^{2+}$-dependent fashion, ${ }^{24,25)}$ but it has no effect on the ATPase activity. Thus, $\mathrm{S} 100$ protein may have a regulatory function on ATPase in microtubules.

Acknowledgment The authors thank Dr. A. Hachimori for helpful discussions and for constructive criticism of the manuscript.

\section{References}

1) P. Dustin, "Microtubules," 2nd ed., Springer-Verlag, Berlin, Heidelberg, New York, Tokyo, 1984.

2) V. I. Gelfand, F. K. Gyoeva, V. A. Rosenblat, and N. A. Shanina, FEBS Lett., 88, 197 (1978).

3) K. Prus and M. Wallin, Histochemistry, 78, 181 (1983).

4) H. D. White, B. A. Coughlin, and D. L. Purich, J. Biol. Chem., 255, 486 (1980).

5) T. Endo and H. Hidaka, FEBS Lett., 161, 235 (1983).

6) R. Donato, T. Isobe, and T. Okuyama, FEBS Lett., 186, 65 (1985).

7) T. Fujii, N. Gocho, V. Akabane, Y. Kondo, T. Suzuki, and K. Ohki, Chem. Pharm. Bull., 34, 2261 (1986).

8) J. Patel and P. J. Marangos, Biophys. Res. Commun., 109, 1089 (1982).

9) J. Patel, P. J. Marangos, W. E. Heydorn, G. Chang, A. Verma, and D. Jacobowitz, J. Neurochem., 41, 1040 (1983).

10) J. Baudier, N. Glasser, K. Haglid, and D. Gerard, Biochim. Biophys. Acta, 790, 164 (1984).

11) T. Fujii, N. Gocho, Y. Akabane, M. Fujii, Y. Kondo, T. Suzuki, and K. Ohki, Chem. Pharm. Bull., 34, 5040 (1986).

12) J. Bandier, N. Glasser, and D. Gerard, J. Biol. Chem., 261, 8192 (1986).

13) N. Ishioka, T. Isobe, T. Okuyama, Y. Numata, and H. Wada, Biochim. Biophys. Acta, 625, 281 (1980).

14) T. Fujii, Y. Kondo, M. Kumasaka, and K. Ohki, J. Neurochem., 39, 1587 (1982).

15) Y. Ihara, T. Fujii, T. Arai, R. Tanaka, and Y. Kaziro, J. Biochem. (Tokyo), 86, 587 (1979).

16) O. H. Lowry, N. J. Rosebrough, A. L. Farr, and R. J. Randall, J. Biol. Chem., 193, 265 (1951).

17) V. D. Lee, R. H. Himes, and L. Wilson, J. Mol. Biol., 171, 457 (1983).

18) R. Donato, J. Neurochem., 42, 1468 (1984).

19) R. Donato, Cell Calcium, 7, 123 (1986).

20) B. C. Webb, Arch. Biochem. Biophys., 198, 296 (1979).

21) F. Solomon, Biochemistry, 16, 358 (1977).

22) L. Karr, D. Kristofferson, and D. L. Purich, J. Biol. Chem., 255, 11853 (1980).

23) D. R. Marshak, T. J. Lukas, and D. M. Watterson, Biochemistry, 24, 144 (1985).

24) J. Marcum, J. R. Dedman, B. R. Brinkley, and A. R. Means, Proc. Natl. Acad. Sci. U.S.A., 75, 3771 (1978).

25) S. A. Berkowita and J. Wolf, J. Biol. Chem., 256, 11216 (1981). 